\title{
АНТИМИКРОБНЫЕ СВОЙСТВА ГИДРОГЕЛЕЙ НА ОСНОВЕ ГЛИЦЕРОЛАТОВ КРЕМНИЯ, ТИТАНА, ЦИНКА И БОРА
}

\author{
Е.Ю. Никитина', Е.В. Шадрина', Н.П. Евстигнеева², М.М. Кохан², \\ М.А. Булатова ${ }^{1,3}$, Т.Г. Хонина'
}

${ }^{1}$ Институт органического синтеза им. И.Я. ПостовскогоУральского отделения Российской академии наук, 620108, Россия, г. Екатеринбург, ул. С. Ковалевской, д. 22.

2Уральский научно-исследовательский институт дерматовенерологии и иммунопатологии,620076, Россия, г. Екатеринбург, ул. Щербакова, д. 8.

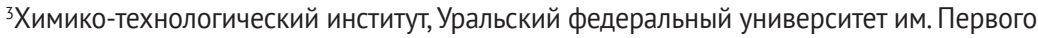
президента России Б.Н. Ельцина, 620002, Россия, г. Екатеринбург, ул. Мира, д. 19.

DOI: 10.19163/MedChemRussia2021-2021-314

E-mail:mariabulatov@gmail.com

Ранее в Институте органического синтеза им. И.Я. ПостовскогоУрО РАН золь-гель методом на основе глицеролатов кремния, титана, цинка и бора были синтезированы фармакологически активные $\mathrm{Si}$-, Si, Ti-,Si,B-, Si,Zn-,

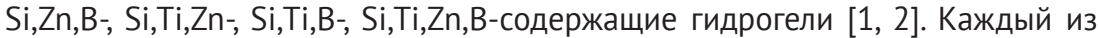
микроэлементов в их составе обеспечивает определенный вид биоактивности: кремний - ранозаживляющую, титан - антиоксидантную, цинк - иммунотропную и антибактериальную, бор - антисептическую.

Целью данной работы являлась сравнительная оценка антимикробной (антибактериальной и противогрибковой) активности синтезированных гидрогелей.

Антимикробную активность оценивали методом диффузии в агар (положительный контроль: 3\%-я тетрациклиновая мазь и 1\%-й раствор экзодерила, соответственно) относительностандартных штаммов микроорганизмов. Установлен ряд антимикробной активности: Si,Zn,B- $\approx \mathrm{Si}, \mathrm{Ti}, \mathrm{Zn}, \mathrm{B}->\mathrm{Si}, \mathrm{B}-\approx$ $\mathrm{Si}, \mathrm{Ti}, \mathrm{B}->\mathrm{Si}, \mathrm{Zn}-\approx \mathrm{Si}, \mathrm{Ti}, \mathrm{Zn}$-гель;Si- и Si,Ti-гель антимикробными свойствами не обладают. Показано, что введение глицеролатов титана в состав гелей не оказывает влияния на антимикробные свойства. Высокаяактивность Si,Zn,Bи Si,Ti,Zn,B-геля, сопоставимая, ав ряде случаев и превышающая контроль, объясненаодновременным присутствием в их дисперсионной среде катиона $\mathrm{Zn}^{2+}$ и бисглицероборат-аниона $\left[\mathrm{B}\left(\mathrm{C}_{3} \mathrm{H}_{6} \mathrm{O}_{3}\right)_{2}\right]$. Наиболее активныеSi,Zn,B- $и$ $\mathrm{Si}, \mathrm{Ti}, \mathrm{Zn}, \mathrm{B}$-гели можно рассматривать как эффективную и безопасную альтернативу местно применяемым антибиотикам.

Работа выполнена в соответствии с планами НИР и государственным заданием на 2021 г. (государственная регистрация № AAAA-A19-119011790130-3).

\section{Литература}

[1] T.G. Khonina, N.V. Kungurov, N.V. Zilberberg et al., J. Sol-Gel Science and Technology. 2020. 95, 682-692.

[2] Т.Г. Хонина, Е.Ю. Никитина, Е.В. Шадрина и др., Изв. Академии наук. Серия химическая. 2021. 70, 967-974. 